\title{
Effect of Growth Promoter Supplement on Yield and Grain Quality of Maize (Zea mays $\mathrm{L}$ )
}

\author{
H.M. Abdel-Lattif, R. Absy ${ }^{\#}$ and M.M. Atta \\ Agronomy Department, Faculty of Agriculture, Cairo University, Giza, Cairo, Egypt.
}

\begin{abstract}
$\mathbf{G}$ ROWTH promoters or biostimulants have been called for the supplements that contain nutrients, amino acids and plant extracts. One of them would be taken into consideration to increase the production of plants is the growth promoter VIUSID agro. To study the effect of VIUSID agro on the maize grain yield (ton $\mathrm{ha}^{-1}$ ) as well as grain quality, two field experiments were carried out in the experimental field of Agric. Res. Stat., Fac. Agric., Cairo Univ., Giza, Egypt in 2015 and 2016 seasons. With this aim, five maize cultivars (Namely, the single cross hybrids SC-30k9, SC-110, SC-30k8, the three way cross hybrid TWC-310 and the openpollinated composite Cairo-1) were evaluated under four dosages, i.e., 0.0, 0.96, 1.44 and 2.0L $\mathrm{ha}^{-1}$ of foliar spraying of theVIUSID agro. Means under the dosage of $0.96 \mathrm{~L} \mathrm{ha}^{-1}$ of theVIUSID agro significantly exceeded the control by $26.19 \%$ for grain yield ha ${ }^{-1}(\mathrm{GYH}), 8.89 \%$ for grain protein percentage (GP\%), 45.39\% for protein yield/ha, 3.14\% for grain oil percentage (GO\%), $40.44 \%$ for oil yield $\mathrm{ha}^{-1}(\mathrm{OYH})$ and $33.29 \%$ for carbohydrate yield/ha. It was concluded that increasing maize yield ha ${ }^{-1}$ and grain quality in the present investigation could be achieved by applying the low dosage $\left(0.96 \mathrm{~L} \mathrm{ha}^{-1}\right)$ of VIUSID agro.
\end{abstract}

Keywords: Amino acids, Bioactive compounds, Biostimulants, Maize (Zea mays L), VIUSID agro.

\section{Introduction}

Maize (Zea mays L) is the third important cereal crop after wheat (Triticum aestivum $\mathrm{L}$ ) and rice (Oryza sativa L). It cultivated for several purposes, such as human consumption, livestock and poultry feed, manufacturing starch and cooking oils as well as fermentation industries. Maize is also grown for green fodder and silage. Grain quality is an important objective in maize breeding (Mazur et al., 1999 and Wang \& Larkins, 2001). Some of the most important traits of interest in the maize market are those related to the nutritional quality of the grain, especially protein and oil content (Mittelmann et al., 2003). In a typical hybrid maize, grain contains approximately $73 \%$ starch, 9\% protein, $4 \%$ oil and $14 \%$ other constituents (mostly fiber), and the oil is stored mainly in the germ, while starch and protein are found primarily in the endosperm, which makes up the majority of the kernel (Tan \& Morrison, 1979). It supplies around one-fourth of the world's cereal protein (Jalil \& Tahir, 1970). In Asia and Africa, almost all the maize produced is used for food, and therefore its contribution to dietary calories and proteins is substantial (Rooney \& Serna-
Saldivar, 1987). Maize oil is characterized by high levels of unsaturated fatty acids, especially oleic (18:1); including this grain in the diet would have positive health effects (Weber, 1970 and Zai $\&$ Gao, 2001). Nutritional quality of maize grain could be improved by some agricultural practices such as $\mathrm{N}$ supplement. In this aspect, Uribelarrea et al. (2004) found that abundant nitrogen supply stimulated protein synthesis in high protein genotypes and that protein and oil had a positive correlation.

In recent years, the use of biostimulants in sustainable agriculture has been growing so; using the biostimulants to promote plant growth has recently acquired expanding attention worldwide (Ertani et al., 2013 and Nardi et al., 2016). Supplements that contain nutrients, amino acids and plant extracts have been called "growth promoters" or the "biostimulants" (Peña et al., 2017). Nardi et al. (2016) reported that the biostimulants can be obtained from different organic materials and include humic substances, complex organic materials, beneficial chemical elements, peptides and amino acids, inorganic salts, seaweed extracts, chitin and chitosan 
derivatives, antitranspirants, amino acids and other N-containing substances. They added that application of the biostimulants to plants leads to higher content of nutrients in their tissue and positive metabolic changes. In addition, the biostimulants influence plant growth and nitrogen metabolism, especially because of their content in hormones and other signaling molecules. As they refer above, a significant increase in root hair length and density is often observed in plants treated with the biostimulants, suggesting that these substances induce a "nutrient acquisition response" that favors nutrient uptake in plants via an increase in the absorptive surface area. Furthermore, the biostimulants positively influence the activity and gene expression of enzymes functioning in the primary and secondary plant metabolism.

One of those biostimulants would be taken into consideration to increase the production of plants is the growth promoter of the VIUSID agro since, according to Catalysis (2014), it acts as a natural bioregulator and is basically composed of amino acids, vitamins and minerals (Peña et al., 2017). In addition, as a relevant aspect, all of its components are subjected to a biocatalytic process of molecular activation that allows the use of low dosages with good results. Experiments were conducted in several crops where the VIUSID agro application lead to an increase in production. One was for beans (Phaseolus vulgaris L) (Peña et al., 2015a). It was also found that it increased the quality of the leaves of the anthurium (Anthurium andreanum Lind.) and the start of flowering (Peña et al., 2015b), as well as the germination of the seed and the production of tomatoes (Solanum lycopersicum L) (Peña et al., 2016). Peña et al. (2017) evaluated the effect of VIUSID agro in the productive performance of lettuce (Lactuca sativa L), Swiss chard (Beta vulgaris var. cicla), beetroot (Beta vulgaris L) and radish (Raphanus sativus L) in terms of organoponics or urban agriculture. Yields increased in the most favorable treatments by $30.66 \%$ in lettuce (Lactuca sativa), 25.90\% in chard and over $50 \%$ in beetroot and radish. Moreover, Atta et al. (2017) study the effect of VIUSID agro on maize to determine the optimal dosage of VIUSID agro which increase maize grain yield. They concluded that increasing maize grain yield was obvious for most studied cultivars by applying the dosage of $0.96 \mathrm{~L} \mathrm{ha}^{-1}$ of theVIUSID agro than other dosages, it was significantly exceeded the control by $26.0 \%$.
The amino acids which is involved in the VIUSID agro composition is well known the the biostimulant which has positive effects on plant growth and yield as well as helping the plants to overcome the harmful effect caused by abiotic stress (Kowalczyk \& Zielony, 2008). In addition, the amino acids have several other roles in plants, e.g., they regulate ion transport and stomatal opening and affect the synthesis and activity of enzymes and gene expression (Rai, 2002). Oaks, (1994) reported that the amino acids are the first stable products of inorganic $\mathrm{N}$ assimilation and are the building blocks for proteins. Changes in the concentration of several amino acids or the total amino acids have been shown to be involved in the regulation of many processes related to the nitrogen metabolism of the plant. Furthermore, bioactive compounds, such as glycyrrhizin is usually produced as a mixture of potassium and calcium salts in plants (Zhang et al., 1995 and Paolini et al., 1999) and was identified to be the major active component for its commercial value (Shibata, 2000 and Liu et al., 2007). In respect to the zinc element, it is a member of more than 300 enzymes in plants and it can be incorporated in the protein solution (Coleman, 1992). In addition, glucosamine is an amino sugar and a prominent precursor in the biochemical synthesis of glycosylated proteins and lipids (Pigman et al., 1980).

The present investigation is the first attempt to study the effect of VIUSID agro on maize grain composition therefore, the objectives of the present work were to: (1) Determine the effect of VIUSID agro on maize grain protein, oil and carbohydrate; (2) Study genotypic differences among five maize cultivars as affected by different dosages of the VIUSID agro and (3) Identify the relationships among studied traits and the different dosages of VIUSID agro for each studied cultivar.

\section{Materials and Methods}

Two field experiments were carried out at the Agricultural Research and Experiment Station of Faculty of Agriculture, Cairo University, Giza, Egypt $\left(30^{\circ} 02^{\prime} \mathrm{N}\right.$ and $31^{\circ} 13^{\prime} \mathrm{E}$, with above sea level $30 \mathrm{~m}$ ) during the two successive seasons of 2015 and 2016. The climatic variables in the two seasons are presented in Table 1. Soil properties of 2015 and 2016 seasons (Table 2) were analyzed at Reclamation and Development Center Desert Soils, Faculty of Agriculture Research Park, Cairo University. 
TABLE 1. Some climatic variables recorded at Giza location in 2015 and 2016:

\begin{tabular}{lcccc}
\hline \multirow{2}{*}{ Month } & \multicolumn{2}{c}{$\mathbf{2 0 1 5}$} & \multicolumn{2}{c}{$\mathbf{2 0 1 6}$} \\
\cline { 2 - 5 } & Temperature $\left({ }^{\circ} \mathbf{C}\right)$ & $\begin{array}{c}\text { Relative humidity } \\
(\%)\end{array}$ & Temperature $\left({ }^{\circ} \mathbf{C}\right)$ & $\begin{array}{c}\text { Relative humidity } \\
(\%)\end{array}$ \\
\hline June & 29.1 & 44.9 & 29.9 & 47.4 \\
July & 32.2 & 46.5 & 28.9 & 57.5 \\
August & 33.2 & 46.6 & 29.3 & 57.9 \\
September & 32.8 & 46.7 & 27.8 & 56.2 \\
\hline
\end{tabular}

*Data obtained by the Central Laboratory for Agricultural Climate (CLAC), Agricultural Research Center (ARC), Egypt. Precipitation was not detected in both seasons.

TABLE 2. Soil analysis results.

\begin{tabular}{|c|c|c|}
\hline Soil analysis & 2015 & 2016 \\
\hline \multicolumn{3}{|l|}{ Physical properties } \\
\hline Sand $(\%)$ & 33.3 & 33.2 \\
\hline Silt (\%) & 30.2 & 31.5 \\
\hline Clay $(\%)$ & 36.5 & 35.3 \\
\hline Texture class & Clay loam & Clay loam \\
\hline \multicolumn{3}{|l|}{ Chemical properties } \\
\hline $\mathrm{PH}_{(1: 1)}$ & 7.5 & 7.7 \\
\hline $\mathrm{Ec}_{(1: 1)}\left(\mathrm{dS} \mathrm{m}^{-1}\right)$ & 1.9 & 1.9 \\
\hline Organic matter $(\%)$ & 2.3 & 2.2 \\
\hline Total $\mathrm{Ca} \mathrm{Co}_{3}(\%)$ & 3.4 & 3.5 \\
\hline Available N (mg kg-1 $)$ & 35.4 & 40.9 \\
\hline Available P (mg kg-1 $)$ & 9.0 & 9.9 \\
\hline Available K (mg kg-1 ) & 210.0 & 230.0 \\
\hline \multicolumn{3}{|l|}{ Irrigation water analysis } \\
\hline Ec of Irrigation water $\left(\mathrm{dsm}^{-1}\right)$ & 0.78 & 0.86 \\
\hline $\mathrm{pH}$ of Irrigation water & 7.02 & 7.50 \\
\hline Irrigation system & Flooding & Flooding \\
\hline
\end{tabular}

\section{Plant material}

The genetic materials used in this study included five cultivars (Namely, the single cross hybrids SC-30k9, SC-110, SC-30k8, the three way cross hybrid TWC-310 and the open-pollinated composite Cairo-1 (Table 3).

\section{Experimental design and treatments}

A split-plot design in a randomized complete blocks design was used with four replications. The main plots were allotted to the four foliar spraying doses of theVIUSID agro and genotypes were devoted to sub-plot. Each sub-plot consists of 20 rows of $0.70 \mathrm{~m}$ in width and $4.0 \mathrm{~m}$ in length, i.e., the experimental plot area was adjusted as $56 \mathrm{~m}^{2}$. Each main plot was surrounded with a wide row (1.5m) to avoid interference of the four doses of
VIUSID agro. The composition of VIUSID agro is given in Table 4. The four doses of VIUSID agro were applied by foliar spraying after ten days from sowing date and they were given in Table 5.

\section{Cultural practices}

The preceding crop was bread wheat (Triticum aestivum $\mathrm{L}$ ) in both seasons. Sowing was done on the date of June 3 and 6 in 2015 and 2016 seasons, respectively. Seeds were sown in hills at $25 \mathrm{~cm}$ apart by hand, thereafter (before the $1^{\text {st }}$ irrigation) were thinned to one plant per hill. Calcium super phosphate fertilizer $\left(15.5 \% \mathrm{P}_{2} \mathrm{O}_{5}\right)$ at the rate of $60 \mathrm{~kg} \mathrm{P}_{2} \mathrm{O}_{5} /$ ha was applied uniformly before the sowing. Ammonium nitrate $(33.5 \% \mathrm{~N})$ at the rate of $240 \mathrm{~kg} \mathrm{~N} \mathrm{ha}^{-1}$ was added in two equal doses before the first and second irrigations. Standard 
agricultural practices were followed throughout the growing seasons. The weed management was carried out during the growing season by hoeing twice times, before the $1^{\text {st }}$ and the $2^{\text {nd }}$ irrigations and the pest control, if necessary, was done according to practices used at the experimental station. The other cultural practices were applied as recommended by the Agricultural Research Center, Giza, Egypt during the research.

\section{Data collection}

At harvest the following data were recorded:

1- Grain yield per hectare in ton ha ${ }^{-1}$ was calculated by weighing grain yield in $\mathrm{kg}$ from whole area of each experimental unit (sub-plot, each sub-plot consists of 20 rows) and then it adjusted (on the basis of $15.5 \%$ grain moisture content) into ton per hectare (ton ha ${ }^{-1}$ ). (Joe Lauer, 2002).
2- Grain protein percentage (GP \%) according to A.O.A.C. (1995).

3- Grain oil percentage (GO \%) according to A.O.A.C. (2000).

4- Grain carbohydrate percentage (GC \%) according to Minhas et al.(2014).

5- Protein yield per hectare in ton/ha, calculated by multiplying GP \% by grain yield per hectare. (Damir FABIJANAC et al., 2006)

6- Oil yield per hectare in ton/ha, calculated by multiplying GO \% by grain yield per hectare. (Damir FABIJANAC et al., 2006)

7- Carbohydrate yield per hectare in ton/ha, calculated by multiplying GC \% by grain yield per hectare. (Damir FABIJANAC et al., 2006)

Analyses of GP \%, GO \% and GC \% were done at Faculty of Agriculture Research Park, Faculty of Agriculture, Cairo University.

TABLE 3. Cultivar name and institution of development of five studied maize cultivars.

\begin{tabular}{ll}
\hline Cultivar Name & \multicolumn{1}{c}{ Institution } \\
\hline SC-30k9 & Pioneer International Company in Egypt: Pioneer \\
SC-110 & Agricultural Research Center: ARC \\
SC-30k8 & Pioneer \\
TWC-310 & ARC \\
Cairo-1 & Local open-pollinated composite developed at Agronomy Department, Faculty of Agriculture, \\
& Cairo university. \\
\hline
\end{tabular}

TABLE 4. Chemical composition Components \% of VIUSID agro (\%).

\begin{tabular}{lc}
\hline Components & $\%$ \\
\hline Potassium phosphate & 5 \\
Malic acid & 4.6 \\
Glucosamine & 4.6 \\
Arginine & 4.15 \\
Glycine & 2.35 \\
Ascorbic acid & 1.15 \\
Calcium pantothenate & 0.115 \\
Pyridoxal & 0.225 \\
Folic acid & 0.05 \\
Cyanocobalamin & 0.0005 \\
Monoammonium glycyrrizinate & 0.23 \\
Zinc sulphate & 0.115 \\
\hline
\end{tabular}


TABLE 5. Characterization of VIUSID agro treatments.

\begin{tabular}{lcccc}
\hline Treatments & $\begin{array}{c}\text { Dose per application } \\
\text { (L/ha) }\end{array}$ & $\begin{array}{c}\text { Interval of } \\
\text { applications (days) }\end{array}$ & $\begin{array}{c}\text { Number of } \\
\text { applications }\end{array}$ & $\begin{array}{c}\text { Total dose } \\
\text { (L/ha) }\end{array}$ \\
\hline Control & 0 & 0 & 0 & 0 \\
Low & 0.192 & 14 & 5 & 0.96 \\
Medium & 0.206 & 10 & 7 & 1.44 \\
High & 0.200 & 7 & 10 & 2.00 \\
\hline
\end{tabular}

\section{Statistical analysis}

Test of normality distribution was carried out according to method of Shapiro \& Wilk (1965), by using SPSS v. 17.0 (2008) statistical-software. Also, all obtained data were tested for violation of assumptions underlying the combined analysis of variance by separately analyzing of each season and then combined analysis across the two seasons was performed if homogeneity (Bartlet test) was insignificant. Estimates of LSD valuations were calculated to test the significance of differences among means according to Snedecor \& Cochran, (1994), and relationship among the investigated traits with different doses of the VIUSID agro was done according to Steel et al. (1997). Similarly, the trend analysis was done to identify the treatments showing the optimum value for each cultivar by using SPSS v. 17.0 (2008) statistical software.

\section{Results}

\section{Descriptive analysis}

The following statistics were calculated for each variableas minimum, mean, maximum and measures of dispersion, standard deviation, standard error and coefficient of variation. Then, the normal distribution of the data was determined with the Shapiro \& Wilk test (1965) (Table 6).Data showed that the coefficient of variation was high for the all characters, except grain protein (\%), oil $(\%)$ and carbohydrate rate $(\%)$. High CV's were recorded in the oil $(40.17 \%)$, protein $(38.01 \%)$ and carbohydrate yield (35.62), along with a wide range of $(0.08-0.48,0.30-1.75$ and $2.30-10.48$ ton $\mathrm{ha}^{-1}$, respectively).

\section{Analysis of variance}

Combined analysis of variance (Table 7) showed that highly significant differences were existed among studied cultivars as well as among studied dosages of VIUSID agro for all studied traits. Mean squares due to years were highly significant for only grain protein and carbohydrate percentages. Moreover, mean squares due to cultivars $\times$ years, dosages $\times$ years and cultivars $x$ dosages interactions were significant or highly significant for all traits except, grain yield/ha, protein yield/ha, oil yield $\mathrm{ha}^{-1}$ and carbohydrate yield $\mathrm{ha}^{-1}$ for cultivars $\times$ years interaction. Also, mean squares due to cultivars $\times$ dosages $\times$ years interaction were highly significant for all studied traits.

TABLE 6. Descriptive statistics and coefficient of variation of the research for all studied traits across 2015 and 2016 seasons.

\begin{tabular}{lccccccc}
\hline Traits & Min. & Mean & Max. & SD & SE Mean & C.V. & W $^{*}$ \\
\hline Grain yield (ton/ha) & 2.92 & 7.53 & 14.33 & 2.81 & 0.31 & 37.32 & 0.965 \\
Grain protein \% & 9.90 & 11.41 & 13.54 & 0.87 & 0.08 & 7.66 & 0.958 \\
Protein yield (ton/ha) & 0.30 & 0.89 & 1.75 & 0.34 & 0.03 & 38.01 & 0.948 \\
Grain oil \% & 2.39 & 3.09 & 4.11 & 0.46 & 0.04 & 14.92 & 0.967 \\
Oil yield (ton/ha) & 0.08 & 0.24 & 0.48 & 0.10 & 0.01 & 40.17 & 0.970 \\
Grain carbohydrate \% & 72.45 & 74.81 & 77.10 & 1.08 & 0.10 & 1.45 & 0.977 \\
Carbohydrate yield (ton/ha) & 2.13 & 5.83 & 10.48 & 2.08 & 0.19 & 35.62 & 0.966 \\
\hline
\end{tabular}

"Test statistic of Shapiro and Wilk. 
TABLE 7. Combined analysis of variance of a split plot design for all studied traits of five maize cultivars evaluated under spraying four dosages of VIUSID agro across 2015 and 2016 seasons.

\begin{tabular}{|c|c|c|c|c|c|c|c|c|}
\hline S.O.V & d.f & $\begin{array}{c}\text { Grain } \\
\text { yield ha-1 }\end{array}$ & $\begin{array}{c}\text { Grain } \\
\text { protein } \\
\%\end{array}$ & $\begin{array}{c}\text { Protein } \\
\text { yield } \\
\text { ha }^{-1}\end{array}$ & $\begin{array}{l}\text { Grain } \\
\text { oil \% }\end{array}$ & $\begin{array}{c}\text { Oil yield } \\
\text { ha }^{-1}\end{array}$ & $\begin{array}{c}\text { Grain } \\
\text { carbohydrate \% }\end{array}$ & $\begin{array}{c}\text { Carbohydrate } \\
\text { yield } \text { ha }^{-1}\end{array}$ \\
\hline Years $(Y)$ & 1 & 0.14 & $0.266^{* *}$ & 0.001 & 0.038 & 0.001 & $0.893 * *$ & 0.033 \\
\hline $\mathrm{R}(\mathrm{Y})$ & 6 & 0.67 & 0.005 & $0.009 *$ & 0.003 & 0.001 & 0.053 & $0.379 *$ \\
\hline Doses (A) & 3 & $96.08 * *$ & $11.492 * *$ & $1.487 * *$ & $0.182 * *$ & $0.105 * *$ & $5.568 * *$ & $53.02 * *$ \\
\hline YA & 3 & $0.88^{*}$ & $0.125^{* *}$ & $0.010 *$ & $0.024 * *$ & $0.002^{*}$ & $0.134 *$ & $0.453 *$ \\
\hline Error $_{(a)}$ & 18 & 0.25 & 0.003 & 0.003 & 0.003 & 0.000 & 0.034 & 0.140 \\
\hline Cultivars (B) & 4 & $163.71 * *$ & $2.317 * *$ & $2.081 * *$ & $0.774 * *$ & $0.183 * *$ & $2.055^{* *}$ & $92.26 * *$ \\
\hline YB & 4 & 0.26 & $0.017 * *$ & 0.003 & $0.026^{* *}$ & 0.000 & $0.285 * *$ & 0.157 \\
\hline $\mathrm{AB}$ & 12 & $15.82 * *$ & $6.19 * *$ & $0.344 * *$ & $2.441 * *$ & $0.028 * *$ & $12.63 * *$ & $8.471^{* *}$ \\
\hline YAB & 12 & $1.38 * *$ & $0.146^{* *}$ & $0.021 * *$ & $0.018 * *$ & $0.002 * *$ & $0.129 * *$ & $0.756^{* *}$ \\
\hline Error $_{(b)}$ & 96 & 0.53 & 0.004 & 0.007 & 0.002 & 0.001 & 0.036 & 0.297 \\
\hline
\end{tabular}

*,** Indicate significant at 0.05 and 0.01 levels of probability, respectively.

Effect of dosages of the VIUSID agro

Means of the studied traits across all studied cultivars as affected by spraying four dosages of VIUSID agro are presented in Fig. 1 and the percentage of change of means of each dosage compared to the control is presented in Table 8. Means under the dosage of $0.96 \mathrm{~L} \mathrm{ha}^{-1}$ of the VIUSID agro significantly exceeded the control by $26.19 \%$ for the grain yield/ha, $8.89 \%$ for the grain protein percentage, $45.39 \%$ for the protein yield/ha, $3.14 \%$ for the grain oil percentage, $40.44 \%$ for the oil yield $\mathrm{ha}^{-1}$ and $33.29 \%$ for the carbohydrate yield ha' ${ }^{-1}$ (Fig.1 and Table 8).

On the other hand, means under the dosage of $1.44 \mathrm{~L} \mathrm{ha-1}$ of VIUSID agro significantly exceeded the control by $11.82 \%$ for the grain protein percentage, $16.31 \%$ for the protein yield $\mathrm{ha}^{-1}$ and $5.46 \%$ for the carbohydrate yield/ha. Furthermore, means under the dosage of $2.0 \mathrm{~L} \mathrm{ha}^{-1}$ significantly exceeded the control by $7.25 \%$ for the grain protein percentage and $2.29 \%$ for the grain oil percentage (Fig.1 and Table 8).

TABLE 8. Change \% due to spraying four dosages of the VIUSID agro (data are combined across 2015 and 2016 seasons).

\begin{tabular}{|c|c|c|c|}
\hline \multirow[b]{2}{*}{ Trait } & \multicolumn{3}{|c|}{ Change \% } \\
\hline & $\begin{array}{c}\text { Control vs. } \\
0.96 \mathrm{~L} \mathrm{ha-1}\end{array}$ & $\begin{array}{l}\text { Control vs. } \\
1.44 \mathrm{~L} \mathrm{ha}^{-1}\end{array}$ & $\begin{array}{l}\text { Control vs. } \\
2.00 \mathrm{~L} \mathrm{ha}^{-1}\end{array}$ \\
\hline Grain yield (ton ha-1) & $-26.19 * *$ & $5.86^{* *}$ & $21.40 * *$ \\
\hline Grain protein $\%$ & $-8.89 * *$ & $-11.82 * *$ & $-7.25 * *$ \\
\hline Protein yield (ton ha-1) & $-45.39 * *$ & $-16.31 * *$ & $10.62 * *$ \\
\hline Grain oil \% & $-3.14 *$ & 1.70 & $-2.29 *$ \\
\hline Oil yield (ton ha-1) & $-40.44 *$ & -2.67 & $12.00^{*}$ \\
\hline Grain carbohydrate $\%$ & $0.60 * *$ & $1.21 * *$ & $0.55 * *$ \\
\hline Carbohydrate yield (ton ha-1) & $-33.29 * *$ & $-5.46^{* *}$ & $16.80 * *$ \\
\hline
\end{tabular}

*,** Indicate significant at 0.05 and 0.01 levels of probability, respectively.

Change $\%=100 \times[($ control - dosage $) /$ control $]$. 


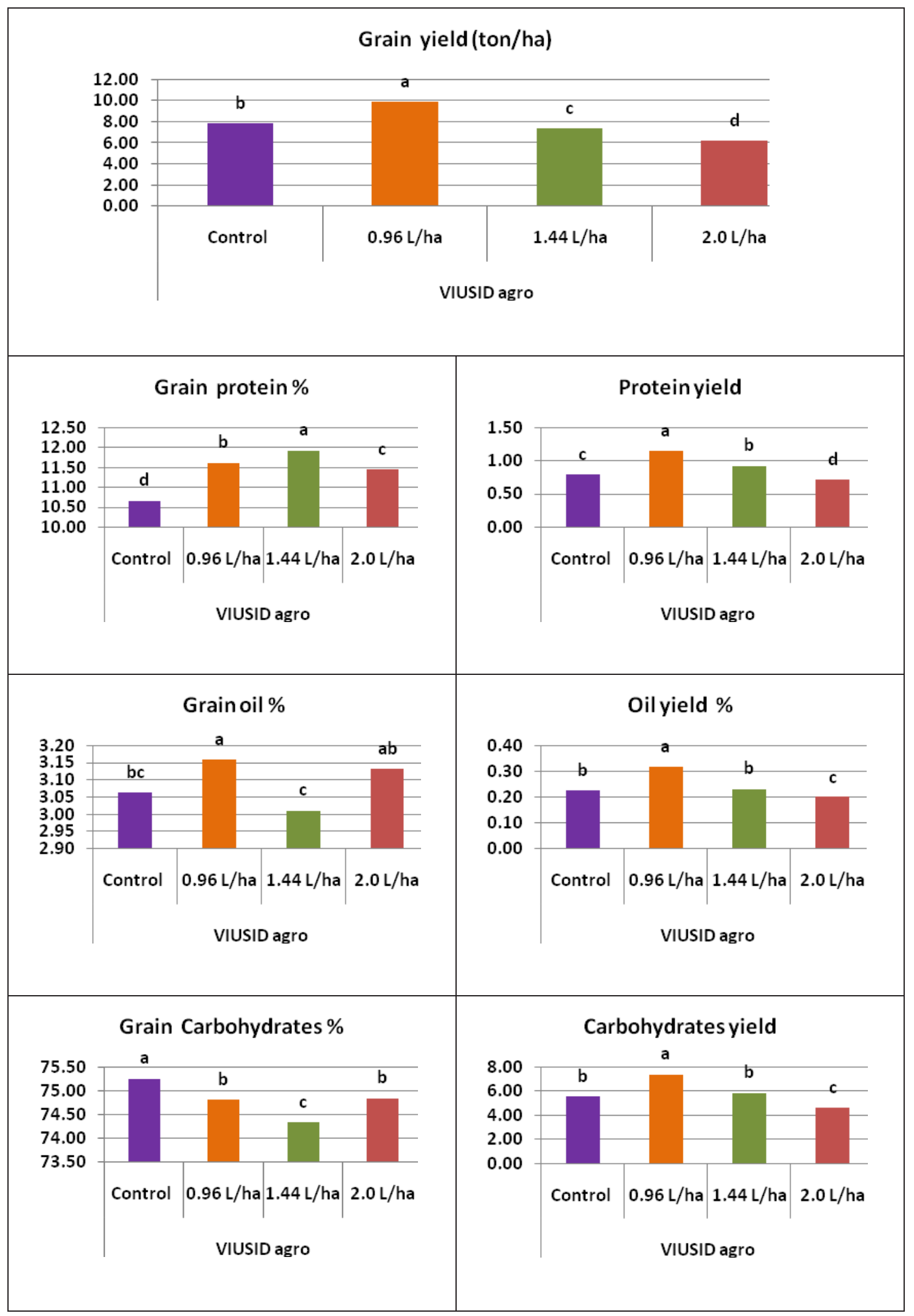

Fig. 1. Mean performance of studied traits across all cultivars under spraying four dosages of VIUSID agro (data are combined across 2015 and 2016 seasons). 


\section{Effect of the cultivars}

Mean performance of the studied cultivars across four dosages of the VIUSID agro (Table 9) showed that the single cross hybrid SC-30k9 was the first best cultivar for the grain yield $\mathrm{ha}^{-1}$, the grain carbohydrate percentage and the carbohydrate yield ha-1 followed by the Cairo-1 TWC-310. It is interesting to mention that Cairo-1 ranked the first best cultivar for the grain oil percentage and the oil yield/ha. On the other hand, SC-30k8 and SC-110 ranked the latest cultivars for the all traits, except the grain protein percentage, the oil yield $h^{-1}$ and the grain carbohydrate percentage for the SC$30 \mathrm{k} 8$, grain carbohydrate percentage and grain oil percentage for theSC-110.

\section{Effect of cultivars $\times$ dosages of the VIUSID agro}

The studied maize cultivars showed significant differences in their absolute mean values under different dosages of the VIUSID agro compared to the control for all studied traits. Therefore, ranks of all studied cultivars under the dosages of $(0.96,1.14$ and 2.0L ha $\mathrm{L}^{-1}$ ) of the VIUSID agro were different from that under control. The percentage of change of means of each dosage compared to control for each cultivar is presented in Table 10.

Under the dosage of $0.96 \mathrm{~L} \mathrm{ha} \mathrm{h}^{-1}$ of theVIUSID agro, for the grain yield $\mathrm{ha}^{-1} \mathrm{SC}-30 \mathrm{k} 8$ and SC$30 \mathrm{k} 9$ significantly exceeded the control by $81.61 \%$ and $37.32 \%$, respectively. Insignificant increases for grain yield ha ${ }^{-1}$ was also observed for SC-110 (14.23\%), TWC-310 (9.66\%) and Cairo-1 (7.18\%). Significant or highly significant of increasing due to the dosage of $0.96 \mathrm{~L} \mathrm{ha}^{-1}$ for the protein percentage was also detected. The grain protein percentage increased by $20.66 \%$ (SC-30k8), $13.61 \%$ (SC$30 \mathrm{k} 9$ ), 9.14\% (Cairo-1) and 6.39\% (SC-110). Furthermore, the protein yield ha $^{-1}$ increased by $154.1 \%$ (SC-30k8), 70.86\% (Cairo-1), 60.02\%
(SC-30k9) and 19.13\% (SC-110). The grain oil percentage increased by $55.83 \%$ (SC-110) and $2.66 \%$ (TWC-310). The oil yield ha ${ }^{-1}$ increased by $75.0 \%$ (SC-110), 73.45\% (SC-30k8), 48.67\% (Cairo-1) and 31.85\% (SC-30k9). Also, the grain carbohydrate percentage increased by $1.78 \%$ (TWC-310) and the carbohydrate yield increased by $104.49 \% \quad$ (SC-30k8), 55.46\% (Cairo-1), $38.48 \%$ (SC-30k9) and 12.04\% (SC-110) as shown in Table 10.

Under the dosage of $1.44 \mathrm{~L} \mathrm{ha} \mathrm{h}^{-1}$ of theVIUSID agro, yield significantly increased by $28.02 \%$ (SC-110) and 16.95\% (TWC-310). In addition, the grain protein percentage increased by $30.53 \%$ (SC-30k8), 24.61\% (Cairo-1), 11.28\% (SC-110) and $4.40 \%$ (TWC-310). The protein yield $\mathrm{ha}^{-1}$ increased by $81.57 \%$ (Cairo-1) and $50.84 \%$ (SC$30 \mathrm{k} 8)$. Also, grain oil percentage increased by $47.25 \%$ (SC-110) and 26.98\% (TWC-310). The oil yield ha ${ }^{-1}$ increased by $28.89 \%$ (SC-110). The grain carbohydrate percentage increased by $1.26 \%$ (SC$30 \mathrm{k} 9$ ) and the carbohydrate yield ha ${ }^{-1}$ increased by $44.03 \%$ (Cairo-1) by applying $1.44 \mathrm{~L} \mathrm{ha}^{-1}$ (Table 10 )

Under the dosage of $2.0 \mathrm{~L} \mathrm{ha}^{-1}$ of the VIUSID agro, the grain yield ha ${ }^{-1}$ increased (but insignificant) by $7.47 \%$ (SC-30k8) and $4.78 \%$ (TWC-310). The grain protein percentage significantly increased by 14.93\% (Cairo-1), 8.16\% (SC-110), 7.67\% (SC$30 \mathrm{k} 8$ ), $4.48 \%$ (TWC-310) and 1.54\% (SC-30k9) as well as the protein yield increased by $34.64 \%$ (SC-30k8). The grain oil percentage increased by $57.22 \%$ (TWC-310) and 16.22\% (SC-110) and the oil yield ha ${ }^{-1}$ increased by $41.01 \%$ (TWC-310). Also, the grain carbohydrate percentage and the carbohydrate yield ha $^{-1}$ increased by $2.96 \%$ (SC$30 \mathrm{k} 9$ ) and $23.15 \%$ (SC-30k8), respectively as shown in Table 10.

TABLE 9. Mean values four dosages of VIUSID agro (data are combined across 2015 and 2016 seasons).

\begin{tabular}{lccccccc}
\hline Cultivar & $\begin{array}{c}\text { Grain } \\
\text { yield } \\
\text { (ton ha-1 }^{-1}\end{array}$ & $\begin{array}{c}\text { Grain } \\
\text { protein } \\
\text { \% }\end{array}$ & $\begin{array}{c}\text { Protein } \\
\text { yield }\end{array}$ & $\begin{array}{c}\text { Grain } \\
\text { oil \% }\end{array}$ & $\begin{array}{c}\text { Oil yield } \\
\text { \% }\end{array}$ & $\begin{array}{c}\text { Grain } \\
\text { carbohydrate } \\
\text { \% }\end{array}$ & $\begin{array}{c}\text { Carbohydrate } \\
\text { yield }\end{array}$ \\
\hline SC-30k9 & 10.25 & 11.33 & 1.17 & 3.07 & 0.32 & 75.11 & 7.68 \\
SC-110 & 6.33 & 11.08 & 0.70 & 3.21 & 0.21 & 75.05 & 4.75 \\
SC-30k8 & 4.82 & 11.74 & 0.57 & 2.86 & 0.14 & 74.59 & 3.59 \\
TWC-310 & 7.95 & 11.62 & 0.92 & 3.07 & 0.24 & 74.57 & 5.93 \\
Cairo-1 & 9.65 & 11.27 & 1.09 & 3.25 & 0.31 & 74.73 & 7.22 \\
LSD $_{0.05}$ & $\mathbf{0 . 3 6}$ & $\mathbf{0 . 0 3}$ & $\mathbf{0 . 0 4}$ & $\mathbf{0 . 0 2}$ & $\mathbf{0 . 0 2}$ & $\mathbf{0 . 0 9}$ & $\mathbf{0 . 2 7}$ \\
\hline
\end{tabular}


TABLE 10. Effect of cultivars $x$ VIUSID agro interaction and change $\%$ of each dosage compared to control for all studied traits (data are combined across 2015 and 2016 seasons).

\begin{tabular}{|c|c|c|c|c|c|c|c|}
\hline \multirow[b]{2}{*}{ Cultivar } & \multicolumn{4}{|c|}{ VIUSID agro treatments } & \multicolumn{3}{|c|}{ Change \% } \\
\hline & Control & $\begin{array}{c}0.96 \\
\text { L ha }^{-1}\end{array}$ & $\begin{array}{l}1.44 \\
\mathrm{~L} \mathrm{ha}^{-1}\end{array}$ & $\begin{array}{c}2.0 \\
\mathrm{~L} \mathrm{ha}^{-1}\end{array}$ & $\begin{array}{l}\text { Control vs. } \\
\text { 0.96L ha }\end{array}$ & $\begin{array}{l}\text { Control vs. } \\
1.44 \mathrm{~L} \mathrm{ha}^{-1}\end{array}$ & $\begin{array}{l}\text { Control vs. } \\
2.0 \mathrm{~L} \mathrm{ha-1}\end{array}$ \\
\hline \multicolumn{8}{|c|}{ Grain yield (ton ha-1) } \\
\hline SC-30k9 & 9.64 & 13.24 & 9.40 & 8.75 & $-37.32 * *$ & 2.52 & 9.27 \\
\hline SC-110 & 6.38 & 7.29 & 8.17 & 3.50 & -14.23 & $-28.02 * *$ & $45.21^{* *}$ \\
\hline $\mathrm{SC}-30 \mathrm{k} 8$ & 4.06 & 7.37 & 3.50 & 4.36 & $-81.61 * *$ & 13.66 & -7.47 \\
\hline TWC-310 & 7.37 & 8.08 & 8.62 & 7.72 & -9.66 & $-16.95^{*}$ & -4.78 \\
\hline Cairo-1 & 11.66 & 12.50 & 8.02 & 6.41 & -7.18 & $31.25 * *$ & $44.99^{* *}$ \\
\hline \multirow{2}{*}{\multicolumn{8}{|c|}{$\begin{array}{c}\text { Cultivars }=0.36 \quad \text { Cultivars } X \text { Doses }=1.01 \\
\text { Grain protein } \%\end{array}$}} \\
\hline & & & & & & & \\
\hline SC-30k9 & 11.15 & 12.67 & 10.17 & 11.32 & $-13.61 * *$ & $8.75^{* *}$ & $-1.54 * *$ \\
\hline SC-110 & 10.41 & 11.07 & 11.58 & 11.26 & $-6.39 * *$ & $-11.28^{* *}$ & $-8.16^{* *}$ \\
\hline $\mathrm{SC}-30 \mathrm{k} 8$ & 10.23 & 12.35 & 13.36 & 11.02 & $-20.66^{* *}$ & $-30.53 * *$ & $-7.67 * *$ \\
\hline TWC-310 & 11.48 & 11.00 & 11.98 & 12.03 & $4.16^{* *}$ & $-4.40 * *$ & $-4.84 * *$ \\
\hline Cairo-1 & 10.05 & 10.96 & 12.52 & 11.55 & $-9.14^{* *}$ & $-24.61 * *$ & $-14.93 * *$ \\
\hline \multirow{2}{*}{\multicolumn{8}{|c|}{$\begin{array}{r}\text { Cultivars }=0.03 \text { Cultivar } \\
\text { Protein yield (ton ha' } \text { ha }^{-1}\end{array}$}} \\
\hline & & & & & & & \\
\hline $\mathrm{SC}-30 \mathrm{k} 9$ & 1.05 & 1.68 & 0.98 & 0.99 & $-60.02 * *$ & 6.49 & 5.34 \\
\hline SC-110 & 0.76 & 0.90 & 0.74 & 0.39 & $-19.13 * *$ & 2.64 & $48.28^{* *}$ \\
\hline $\mathrm{SC}-30 \mathrm{k} 8$ & 0.36 & 0.91 & 0.54 & 0.48 & $-154.19 * *$ & $-50.84 * *$ & $-34.64 * *$ \\
\hline TWC-310 & 0.99 & 0.89 & 0.88 & 0.93 & $10.12 *$ & $10.73^{*}$ & 5.87 \\
\hline Cairo-1 & 0.80 & 1.37 & 1.46 & 0.74 & $-70.86^{* *}$ & $-81.57 * *$ & 7.85 \\
\hline \multirow{2}{*}{\multicolumn{8}{|c|}{$\begin{array}{c}\text { Cultivars }=0.04 \text { Cultiva } \\
\text { Grain oil } \%\end{array}$}} \\
\hline & & & & & & & \\
\hline $\mathrm{SC}-30 \mathrm{k} 9$ & 3.34 & 3.12 & 2.70 & 3.10 & $6.55 * *$ & $19.15^{* *}$ & $7.18 * *$ \\
\hline SC-110 & 2.47 & 3.85 & 3.64 & 2.87 & $-55.83 * *$ & $-47.25 * *$ & $-16.22 * *$ \\
\hline $\mathrm{SC}-30 \mathrm{k} 8$ & 3.23 & 2.67 & 2.82 & 2.71 & $17.49 * *$ & $12.69 * *$ & $16.16^{* *}$ \\
\hline TWC-310 & 2.52 & 2.59 & 3.20 & 3.96 & $-2.66^{* *}$ & $-26.98 * *$ & $-57.22 * *$ \\
\hline Cairo-1 & 3.75 & 3.57 & 2.69 & 3.01 & $4.81^{* *}$ & $28.22 * *$ & $19.55^{* *}$ \\
\hline $\mathrm{LSD}_{0.05}$ & & & Cultivars $=0.02$ & Cultiv & $X$ Doses $=0.04$ & & \\
\hline \multicolumn{8}{|c|}{ Oil yield (ton ha') } \\
\hline $\mathrm{SC}-30 \mathrm{k} 9$ & 0.314 & 0.414 & 0.261 & 0.272 & $-31.85 * *$ & $16.88^{* *}$ & $13.38^{*}$ \\
\hline SC-110 & 0.180 & 0.315 & 0.232 & 0.101 & $-75.00 * *$ & $-28.89 * *$ & $43.89 * *$ \\
\hline $\mathrm{SC}-30 \mathrm{k} 8$ & 0.113 & 0.196 & 0.115 & 0.118 & $-73.45^{* *}$ & -1.77 & -4.42 \\
\hline TWC-310 & 0.217 & 0.209 & 0.236 & 0.306 & 3.69 & -8.76 & $-41.01 * *$ \\
\hline Cairo-1 & 0.300 & 0.446 & 0.313 & 0.193 & $-48.67 * *$ & -4.33 & $35.67 * *$ \\
\hline $\mathrm{LSD}_{0.05}$ & & & Cultivars $=0.015$ & Cultiv & Doses $=0.03$ & & \\
\hline
\end{tabular}

**** Indicate significant at 0.05 and 0.01 levels of probability, respectively. Change $\%=100 \times$ [(control - dosage $) /$ control]. 
TABLE 10. Cont.

\begin{tabular}{|c|c|c|c|c|c|c|c|}
\hline \multirow[b]{2}{*}{ Cultivar } & \multicolumn{4}{|c|}{ VIUSID agro treatments } & \multicolumn{3}{|c|}{ Change \% } \\
\hline & Control & $0.96 \mathrm{~L} \mathrm{ha}^{-1}$ & $1.44 \mathrm{~L} \mathrm{ha}^{-1}$ & 2.0 $\mathrm{L} \mathrm{ha}^{-1}$ & $\begin{array}{c}\text { Control vs. } \\
0.96 \mathrm{~L} \mathrm{ha}^{-1}\end{array}$ & $\begin{array}{c}\text { Control vs. } \\
1.44 \mathrm{~L} \mathrm{ha}^{-1}\end{array}$ & $\begin{array}{c}\text { Control vs. } \\
2.0 \mathrm{~L} \mathrm{ha}^{-1}\end{array}$ \\
\hline \multicolumn{8}{|c|}{ Grain carbohydrate \% } \\
\hline SC-30k9 & 74.65 & 73.35 & 75.59 & 76.85 & $1.73 * *$ & $-1.26^{* *}$ & $-2.96 * *$ \\
\hline SC-110 & 75.19 & 75.19 & 74.62 & 75.18 & 0.00 & $0.76^{* *}$ & 0.02 \\
\hline SC-30k 8 & 76.24 & 74.13 & 72.60 & 75.40 & $2.76^{* *}$ & $4.77 * *$ & $1.09^{* *}$ \\
\hline TWC-310 & 74.83 & 76.17 & 74.25 & 73.04 & $-1.78 * *$ & $0.78 * *$ & $2.40 * *$ \\
\hline Cairo-1 & 75.36 & 75.17 & 74.66 & 73.73 & 0.25 & $0.94 * *$ & $2.17 * *$ \\
\hline $\mathrm{LSD}_{0.05}$ & & & Cultivars $=0.09$ & Cultiva & $\mathrm{X}$ Doses $=0.19$ & & \\
\hline \multicolumn{8}{|c|}{ Carbohydrate yield (ton ha-1) } \\
\hline SC-30k9 & 7.01 & 9.71 & 7.29 & 6.72 & $-38.48 * *$ & -3.89 & 4.14 \\
\hline SC-110 & 5.48 & 6.14 & 4.76 & 2.63 & $-12.04 *$ & $13.17^{*}$ & $52.02 * *$ \\
\hline SC-30k8 & 2.67 & 5.46 & 2.95 & 3.29 & $-104.49 * *$ & -10.37 & $-23.15^{*}$ \\
\hline TWC-310 & 6.45 & 6.16 & 5.47 & 5.64 & 4.57 & $15.19^{* *}$ & $12.56^{* *}$ \\
\hline Cairo-1 & 6.04 & 9.39 & 8.70 & 4.73 & $-55.46^{* *}$ & $-44.03 * *$ & $21.75^{* *}$ \\
\hline $\operatorname{LSD}_{0.05}$ & & & Cultivars $=0.27$ & Cultiva & $\mathrm{X}$ Doses $=\mathbf{0 . 5 4}$ & & \\
\hline
\end{tabular}

*** Indicate significant at 0.05 and 0.01 levels of probability, respectively. Change $\%=100 \times$ [(control - dosage $) /$ control].

Relationships among studied traits and the dosages of VIUSID agro

To evaluate responses of the studied cultivars to the four dosages of theVIUSID agro, data of the present investigation were reanalyzed by using the trend analysis to identify the treatments showing optimum value for each cultivar. The relationships among studied cultivars and the dosages of the VIUSID agro are presented in Fig. 2. For grain yield ha ${ }^{-1}$ the cultivars SC-30k9, SC-110, SC-30k8 and Cairo-1 showed a cubic relationship, with the highest grain yield ha-1 at the dosage of $0.96 \mathrm{~L} \mathrm{ha}^{-1}$ for SC-30k9 (13.24ton ha-1), SC-30k8 (7.37ton $\mathrm{ha}^{-1}$ ), and Cairo-1 (12.5ton ha-1). In respect to SC110 it reached optimum value (8.17ton $\mathrm{ha}^{-1}$ ) at the dosage of $1.44 \mathrm{~L} \mathrm{ha}^{-1}$. On the other hand, the cultivar TWC-310 showed a quadratic relationship with the highest grain yield ha-1 $\left(8.62\right.$ ton $^{-1}$ ) at the dosage of 1.44L ha-1 of theVIUSID agro (Fig. 2).

For the grain protein (\%), all studied cultivars showed a cubic relationship with the highest protein $(\%)$ at the dosage of $1.44 \mathrm{~L} \mathrm{ha} \mathrm{ha}^{-1}$ for SC$110(11.58 \%), \mathrm{SC}-30 \mathrm{k} 8(13.36 \%)$ and Cairo-1 $(12.52 \%)$. On the other hand, the cultivar SC$30 \mathrm{k} 9$ reached optimum value for the grain protein $\%(12.67 \%)$ at the dosage of $0.96 \mathrm{~L} \mathrm{ha}^{-1}$, whereas, the cultivar TWC-310 reached optimum value for the protein $\%(12.03 \%)$ at the dosage of $2.0 \mathrm{~L} / \mathrm{ha}$. Regarding to the protein yield/ha, the cultivar SC-
110, TWC-310 and Cairo-1 showed a quadratic relationship with the highest protein yield ton ha-1 at the dosage of $0.96 \mathrm{~L} \mathrm{ha}^{-1}$ for SC-110 (0.90ton $\left.\mathrm{ha}^{-1}\right)$, at the dosage of $1.44 \mathrm{~L} \mathrm{ha}^{-1}$ for Cairo-1 (1.46 tonha $\left.^{-1}\right)$ and at the control for TWC-310 (0.99 tonha $\left.\mathrm{a}^{-1}\right)$. On the other hand, the cultivar SC-30k9 and SC-30k8 showed a cubic relationship with the highest protein yield at the dosage of $0.96 \mathrm{~L} \mathrm{ha}^{-1}$ for SC-30k9 (1.68ton ha' ${ }^{-1}$ ) and SC-30k8 (0.91 ton ha' $\left.{ }^{-1}\right)$.

In respect to the grain oil (\%) the cultivars SC110 and TWC-310 showed a quadratic relationship with the highest oil $\%$ at the dosage of $0.96 \mathrm{~L} \mathrm{ha}^{-1}$ for SC-110 (3.85\%) and at the dosage of $2.0 \mathrm{~L} \mathrm{ha}^{-1}$ for TWC-310 (3.96\%). The cultivars SC-30k9, SC-30k8 and Cairo-1 showed a cubic relationship with the highest oil (\%) of 3.34, 3.23 and 3.75\% for SC-30k9, SC-30k8 and Cairo-1, respectively at the control. For the oil yield/ha, the cultivars SC110 and TWC-310 showed a quadratic relationship with the highest oil yield at the dosage of $0.96 \mathrm{~L}$ $\mathrm{ha}^{-1}$ for SC-110 (0.315ton ha $\left.{ }^{-1}\right)$ and at the dosage of 2.0L ha $\mathrm{L}^{-1}$ for TWC-310 (0.306ton ha-1). On the other hand, the cultivars SC-30k9, SC-30k8 and Cairo-1 showed a cubic relationship with the highest oil yield at the dosage of $0.96 \mathrm{~L} \mathrm{ha}^{-1}$ for SC$30 \mathrm{k} 9\left(0.414\right.$ ton ha $\left.^{-1}\right)$, SC-30k8 (0.196ton ha $\left.{ }^{-1}\right)$ and Cairo-1 (0.446 ton ha $\left.^{-1}\right)$. 


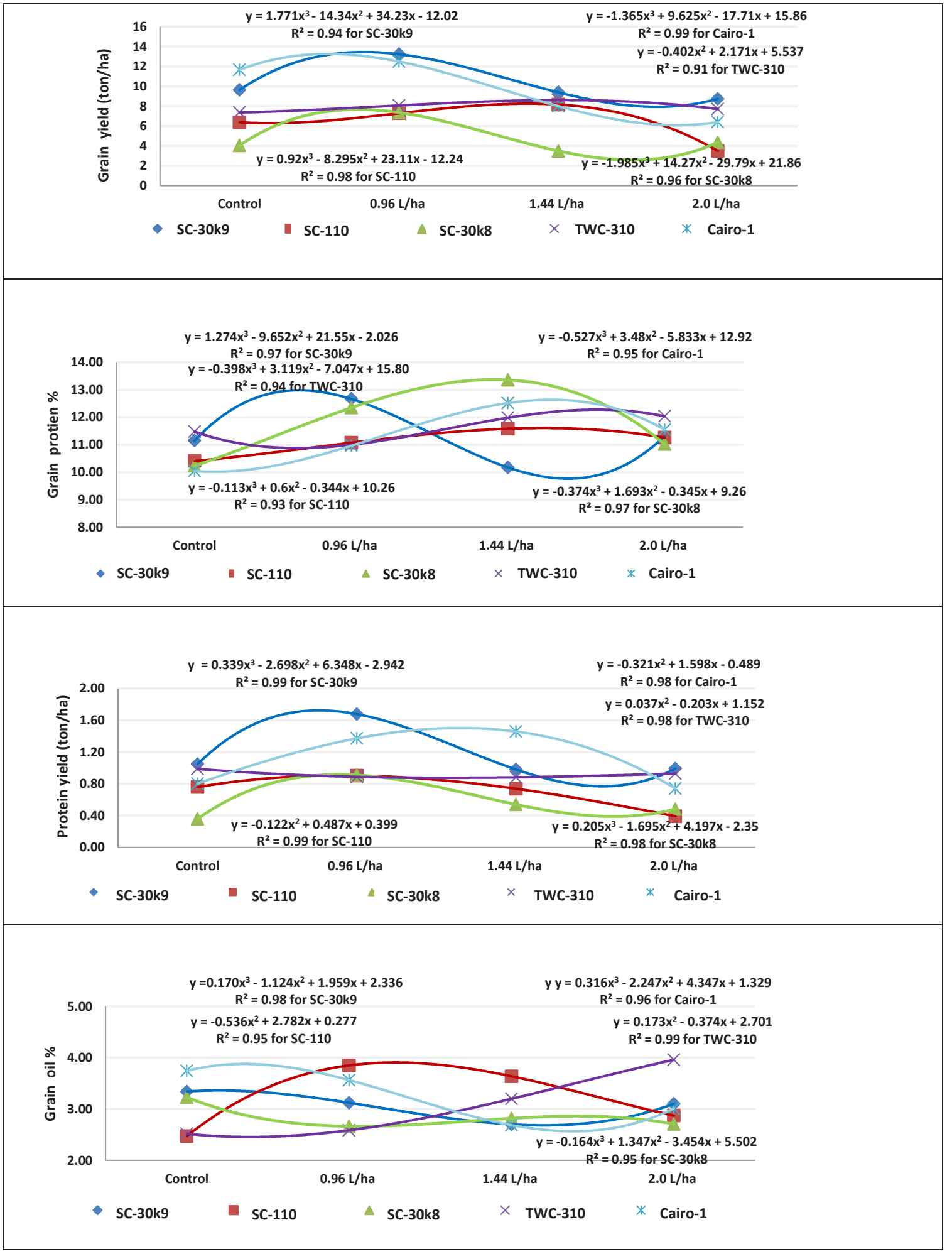

Fig. 2. The relationships among studied cultivars and the dosages of VIUSID agro. 


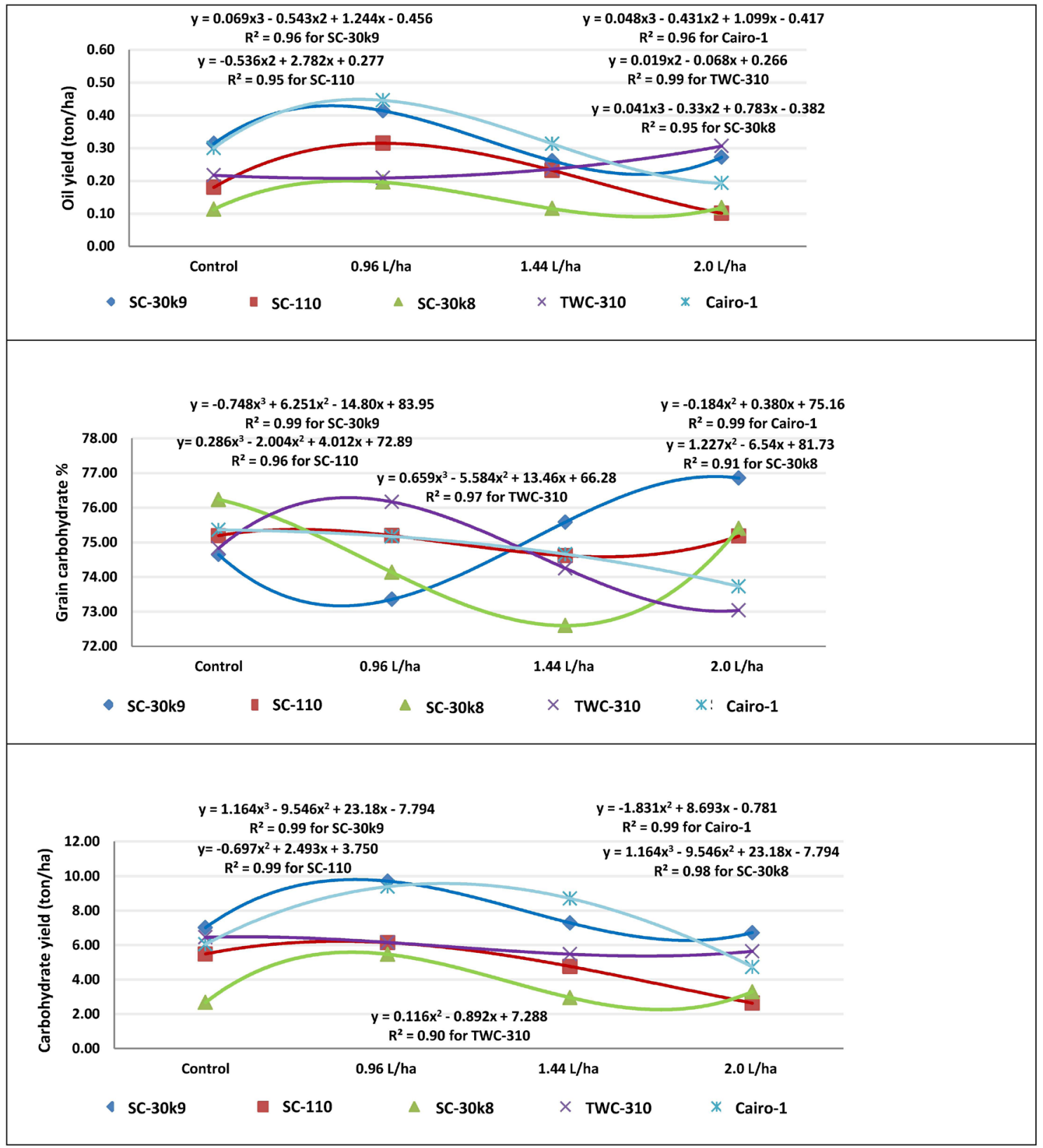

Fig. 2. Cont.

For the carbohydrate (\%), SC-30k8 and Cairo-1 showed a quadratic relationship with the highest carbohydrate $\%$ at the control for SC$30 \mathrm{k} 8(76.24 \%)$ and Cairo-1 (75.36\%). On the other hand, the cultivars SC-30k9, SC-110 and TWC-310 showed a cubic relationship with the highest carbohydrate $\%$ at the dosage of $2.0 \mathrm{~L} \mathrm{ha}^{-1}$ for SC-30k9 $(76.85 \%)$, at the dosage of $0.96 \mathrm{~L} \mathrm{ha}^{-1}$ for TWC-310 $(76.17 \%)$ and at the control or at the dosage of $0.96 \mathrm{~L} \mathrm{ha} \mathrm{ha}^{-1}$ for SC-110 (75.19\%). Regarding to carbohydrate yield/ha, the cultivars SC-110, TWC-310 and Cairo-1 showed a quadratic relationship with the highest carbohydrate yield at the dosage of $0.96 \mathrm{~L} \mathrm{ha}^{-1}$ for SC-110 (6.14ton ha-1) and Cairo-1 (9.39ton ha-1) along with TWC-310 (6.45ton $\left.\mathrm{ha}^{-1}\right)$ at the control. The cultivars SC$30 \mathrm{k} 9$ and SC-30k8 showed a cubic relationship with the highest value of carbohydrate yield at the dosage of $0.96 \mathrm{~L} \mathrm{ha}{ }^{-1}$ for SC-30k9 (9.71ton ha-1) and Sc-30k8 (5.46ton ha-1).

\section{Discussion}

The maize plant supplies around one-fourth of 
the world's cereal protein (Jalil \& Tahir, 1970). In Asia and Africa, almost all the maize produced is used for food, and therefore its contribution to dietary calories and proteins is substantial (Rooney \& Serna-Saldivar, 1987). Nutritional grain quality is an important objective in maize breeding (Mazur et al., 1999 and Wang \& Larkins, 2001). Some of the most important traits of interest in the maize market are those related to the nutritional quality of the grain, especially the protein and the oil content (Mittelmann et al., 2003). The maize oil is characterized by high levels of unsaturated fatty acids, especially oleic (18:1); including this grain in the diet would have positive health effects (Weber, 1970 and Zai \& Gao, 2001). Nutritional quality of the maize grain could be improved by some agricultural practices such as $\mathrm{N}$ supplement. In recent years, the use of biostimulants in sustainable agriculture has been growing so; using biostimulants to promote plant growth has recently acquired expanding attention worldwide (Ertani et al., 2013 and Nardi et al., 2016). Supplements that contain nutrients, amino acids and plant extracts have been called "growth promoters" or "biostimulants" (Peña et al., 2017). Biostimulants positively influence the activity and gene expression of enzymes functioning in the primary and secondary plant metabolism (Nardi et al., 2016). One of those biostimulants would be taken into consideration to increase the production of plants is the growth promoter of the VIUSID agro since, according to Catalysis (2014), it acts as a natural bioregulator and it is basically composed of amino acids, vitamins and minerals (Peña et al., 2017). In addition, as a relevant aspect, all of its components are subjected to a biocatalytic process of molecular activation that allows the use of low dosages with good results. Godlewska \& Ciepiela (2013) evaluated the effect of biostimulant of seaweed (Ecklonia maxima (Osbeck) Papenfuss) extract (the trade name Kelpak SL) on the true protein and simple sugar contents of (Orchard grass) Dactylis glomerata L and Festulolium braunii (K. Richt) A. Camus) different nitrogen rates. They found that the Ecklonia maxima (Osbeck) Papenfuss) extract significantly increased the true protein and the simple sugar contents as well as the sugar/protein ratio in the tested plants.

The present study indicated high level of diversity among the studied cultivars for all studied traits, that provides evidence for sufficient variability and selection on the basis of these traits could be useful. Selection for grain yield could only be effective if desired genetic variability would be presented in the genetic materials. Data of the present investigation are in agreement with those results of Marcos \& Alberto (2013). Moreover, the present study indicated that genotypes and dosages of VIUSID agro had significant effects on all studied traits. It was concluded that the performance of studied cultivars varies with treatments of the VIUSID ago, indicating to the possibility of selection under each specific dosage. Therefore, the suitable cultivar could be identified for each dosage of the VIUSID agro.

Apparent increasing in the grain yield/ ha, the grain protein percentage, the protein yield/ha, grain oil percentage, oil yield $\mathrm{ha}^{-1}$ and carbohydrate yield ha ${ }^{-1}$ was more pronouncing by applying foliar spraying the dosage of $0.96 \mathrm{~L} \mathrm{ha}^{-1}$ of the VIUSID agro (low dosage in the present study) confirming the previous results of (Calvo et al., 2014) for applying biostimulants in small amounts, that able to stimulate nutrient uptake and use efficiency by plants and improve crop quality. Nardi et al. (2009) and Giannattasio et al. (2013) concluded that biostimulants can increase the activity of rhizospher microbes and soil enzymes, the production of hormones and/ or growth regulators in soil and plants, and the photosynthetic process. Furthermore, Ertani et al. (2012) reported that the addition of biostimulants to plants also modifies the morphology of plant roots in a similar way to indole acetic acid (IAA), indicating that they stimulate a "nutrient addition response" that favors the uptake of nutrients via an excesses in the absorptive surface area. It is interesting to remember that the VIUSID agro acts as a natural bioregulator and composed of amino acids, vitamins and minerals and all of its components are subjected to a biocatalytic process of molecular activation that allows the use of low dosage with good result (Peña et al., 2017). Increasing maize yield $\mathrm{ha}^{-1}$ and grain quality under the low dosage $(0.96 \mathrm{~L} / \mathrm{ha}$ ) of VIUSID agro in the present investigation suggesting that the dosage of $0.96 \mathrm{~L} \mathrm{ha}^{-1}$ could be recommended for maximizing maize grain yield as well as grain quality and proved that the biocatalytic process of molecular activation of the components of VIUSID agro allows the use of low dosage with good result. Also, Peña et al. (2017) evaluated the effect of VIUSID agro under low input in the productive performance of lettuce (Lactuca sativa L), Swiss chard, beetroot and radish 
in terms of organoponics or urban agriculture. Yields increased in the most favorable treatments by $30.66 \%$ in lettuce, $25.90 \%$ in chard and over $50 \%$ in beetroot and radish. Moreover, Atta et al. (2017) study the effect of VIUSID agro on maize to determine the optimal dosage of VIUSID agro which increase maize grain yield. They concluded that increasing maize grain yield was obvious for most studied cultivars by applying the dosage of $0.96 \mathrm{~L} \mathrm{ha} \mathrm{h}^{-1}$ of VIUSID agro than other dosages, it was significantly exceeded the control by $26.0 \%$.

It is interesting to mention that the VIUSID agro contains of amino acids in its components, which they have several roles in plants, such as the positive effects on plant growth and yields as well as helping the plants to overcome the harmful effect caused by abiotic stress (Kowalczyk \& Zielony, 2008). In addition, Rai (2002) reported that amino acids regulate ion transport and stomatal opening and affect the synthesis and activity of enzymes and gene expression. Furthermore, they are the first stable products of inorganic $\mathrm{N}$ assimilation and are the building blocks for proteins (Oaks, 1994). In respect to the glycyrrhizin, one of the other VIUSID agro components, it is a bioactive compound and it usually produced as a mixture of potassium and calcium salt in plants (Zhang et al., 1995 and Paolini et al., 1999). The glycyrrhizin, it was identified to be the major active component for its commercial value (Shibata, 2000 and Liu et al., 2007). The zinc element, which it involved in the VIUSID agro components, has a great importance that is a member of more than 300 enzymes in plants and it can be incorporated in the protein solution (Coleman, 1992). In addition, glucosamine is an amino sugar and a prominent precursor in the biochemical synthesis of glycosylated proteins and lipids (Pigman et al., 1980).

Maximum increases for the studied traits was observed by applying the dosage of $0.96 \mathrm{~L} \mathrm{ha} \mathrm{h}^{-1}$ of the VIUSID agro for all studied cultivars with the exception of SC-110 and SC-30k8 for protein percentage and grain yield ha-1 for SC-110, where the dosage of $1.44 \mathrm{~L} \mathrm{ha}^{-1}$ was suitable for them for such traits. On the other hand, the dosage of 2.0L $\mathrm{ha}^{-1}$ was more suitable for TWC-310 to reach maximum increasing for grain protein percentage, grain oil percentage and oil yield/ha. In respect to SC-30k9, it reached maximum increasing for grain carbohydrate percentage by applying the dosage of $2.0 \mathrm{~L} / \mathrm{ha}$.

\section{Conclusion}

The apparent increasing in the grain yield/ha, the grain protein $(\%)$, the protein yield/ha, grain oil (\%), the oil yield $\mathrm{ha}^{-1}$ and the carbohydrate yield $\mathrm{ha}^{-1}$ was more pronouncing by applying foliar spraying the dosage of $0.96 \mathrm{~L} \mathrm{ha}^{-1}$ of the VIUSID agro (low dosage in the present study). Increasing of the maize yield ha ${ }^{-1}$ and the grain quality under the low dosage $(0.96 \mathrm{~L} / \mathrm{ha})$ of the VIUSID agro in the present investigation concluded that the dosage of $0.96 \mathrm{~L} \mathrm{ha} \mathrm{h}^{-1}$ could be recommended for maximizing the maize grain yield as well as grain quality and proved that the biocatalytic process of molecular activation of the components of VIUSID agro allows the use of low dosage with good result.

\section{References}

A.O.A.C. (1995) "Methods of Analysis", Association of Official Agriculture Chemists. $16^{\text {th }}$ ed., Washington D.C., USA. 3172 p.

A.O.A.C. (2000) "Official Methods of Analysis of Association of Official Agriculture Chemists". 17 $7^{\text {th }}$ ed. ByHorwitz, W. Suite (Ed.), Vol. 2(41), pp. 66-68.

Atta, M.M.M., Abdel-Lattif, H.M. and Absy, R. (2017) Influence of biostimulants supplement on maize yield and agronomic traits. Bioscience Research, 14(3), 604-615.

Calvo, P., Nelson, L. and Kloepper, J.W. (2014) Agricultural uses of plant biostimulants. Plant and Soil, 383, 3-41.

Catalysis (2014) VIUSID agro, promotor delcrecimiento. Internet (cited 2014 March 20. Available from: http:// www.catalysisagro.com 2 July 2017.

Coleman, J.A. (1992) Zinc proteins: Enzymes, storage proteins, transcription factors and replication proteins. Annu. Rev. Biochem. 61, 897-946.

Damir FABIJANAC, Boris VARGA, Zlatko SVEČNJAK, Darko GRBEŠA (2006) Grain yield and quality of Semifl int Maize Hybrids at Two Sowing Dates. Agric. Conspec. Sci. 71(2), 45-50

Ertani, A., Pizzeghello, D., Baglieri, A., Cadili, V., Tambone, F., Gennari, M. and Nardi, S. (2012) Agro-industrial residues and their biological activity on maize (Zea mays L) metabolism. Journal of Geochemical Exploration, 129, 103-111. 
Ertani, A., Nardi, S. and Altissimo, A. (2013) Long-term research activity on the biostimulant properties of natural origin compounds. Acta Horticulture, 1009, 181-188.

Giannattasio, M., Vendramin, E., Fornasier, F., Alberghini, S., Zanardo, M., Stellin, F., Concheri, G., Stevanato, P., Ertani, A., Nardi, S., Rizzi, V., Piffanelli, P., Spaccini, R., Mazzei, P., Piccolo, A. and Squartini, A. (2013) Microbiological features and bioactivity of a fermented manure product (Preparation 500) used in biodynamic agriculture. Journal of Microbiology and Biotechnology, 23, 644-651.

Godlewska, A. and Ciepiela, G.A. (2013) The effect of natural growth regulators obtained from Ecklonia maxima and mineral nitrogen on true protein and simple sugar contents of Dactylis glomerata L and Festulolium braunii (K. richt.) A. camus. Turkish Journal of Field Crops, 18(2), 247-253.

Jalil, M.E. and Tahir, M.W. (1970) Review of the world's plant protein resources. In: "Improving Plant Protein by Nuclear Techniques". IAEA, Vienna, pp. 21-32.

Joe Lauer (2002) Methods for calculating corn yield. Field Crops, 28, 47-33.

Kowalczyk, K. and Zielony, T. (2008) Effect of Aminoplant and Asahi on yield and quality of lettuce grown on rockwool. Conf. of biostimulators in modern agriculture, 7-8 Febuary 2008, Warsaw, Poland. 119 p.

Liu, J., Wu, L., Wei, S., Xiao, X., Su, C., Jiang, P., Song, Z., Wang, T. and Yu, Z. (2007) Effects of arbuscular mycorrhizal fungi on growth, nutrient uptake and glycyrrhizin production of licorice (Glycyrrhiza uralensis Fisch). Plant Growth Regul. 52, 29-39.

Marcos, T. and Alberto, C.F. (2013) Multicollinearity in path analysis of maize (Zea mays L). J. of Cereal Sci. 57, 453-462.

Mazur, B., Krebbers, E. and Tingey, S. (1999) Gene discovery and product development for grain quality traits. Science, 285, 372-375.

Minhas, A.H., Asad, M.J., Ilyas, A.I. and Mahmood, R.T. (2014) Estimation of carbohydrate, starch, protein and oil contents of indigenous maize (Zea mays L) germplasm. European Academic Research, 11, 5230-5240.
Mittelmann, A., Miranda, J.B., Lima, G.J.M., Haraklein, C. and Tanaka, R.T. (2003) Potential of the ESA23B maize population for protein and oil content improvement. Sci. Agric. 60(2), 319-327.

Nardi, S., Carletti, P., Pizzeghello, D. and Muscolo, A. (2009) Biological activities of humic substances, in biophysico-chemical processes involving natural nonliving organic matter in environmental systems. In: "Fundamentals and Impact of Mineralorganic-biota Interactions on the Formation, Transformation, Turnover, and Storage of Natural Nonliving Organic Matter (NOM)", Part I. Senesi, N., Xing, B., Huang, P.M. (Ed.). John Wiley, Hoboken, NJ, USA.

Nardi, S., Pizzeghello, D., Schiavon, M. and Ertani, A. (2016) Plant biostimulants: Physiological responses induced by protein hydrolyzed-based products and humic substances in plant metabolism. Review Scientia Agricola, 73(1), 18-23.

Oaks, A. (1994) Primary nitrogen assimilation in higher plants and its regulation. Can. J. Bot. 72, 739-750.

Paolini, M., Barillari, J., Broccoli, L., Perocco, P., Cantelli-Forti, G. (1999) Effect of liquorice and glycyrrhizin on rat liver carcinogen metabolizing enzymes. Cancer Lett. 145, 35-42.

Peña, K., Rodríguez, J.C. and Santana, M. (2015a) Productive behavior of the bean (Phaseolus vulgaris L) treaty with a promoter of the growth activated molecularly. Revista Cientifica Avances, 17(4), 327-337.

Peña, K., Rodríguez, J.C. and Meléndrez, J.F. (2015b) The VIUSID agro an alternative in the increase of tomato production (Solanum lycopersicum L). Revista Granma Ciencia, 19(2), 1-12.

Peña, K., Rodríguez, J.C. and Meléndrez, J.F. (2016) VIUSID agro an alternative in the increase of tomato production (Solanum lycopersicum L). Revista Caribeña de Ciencias Sociales. http://www. eumed.net/rev/caribe/ 2016/05/viusid.html.

Peña, K., Rodriguez, J.C., Olivera, D., Melendrez, J.F., Rodriguez, L., Garcia, R. and Rodriguez, L. (2017) Effects of a growth promoter on different vegetable crops. International J. of Development Res. 7(2), 11737-11743.

Pigman, W.W., Horton, D. and Wander, J.D. (1980) "The 
Carbohydrates". Vol. 1B. New York: Academic Press. pp.727-728. ISBN 9780125563512.

Rai, V.K. (2002) Role of amino acids in plant responses to stresses. Biologia Plantarum, 45(4), 481-487.

Rooney, L.W. and Serna-Saldivar, S.O. (1987) Food uses of whole corn and dry-milled fractions. In: "Corn-Chemistry and Technology", Watson, S.A., Ramstad, P.E. (Ed.), pp 399-429. AACC, St. Paul.

Shapiro, S.S. and Wilk, M.B. (1965) Analysis of variance test for normality (complete samples). Biometrika, 52(3/4), 591-611.

Shibata, S. (2000) A drug over the millennia: Pharmacognosy, chemistry and pharmacology of licorice. YakugakuZasshi-J. Pharma Soc. Jpn. 120(10), 849-862.

Snedecor, G.W. and Cochran, W.G. (1994) "Statistical Methods". $9^{\text {th }}$ ed., Iowa State Univ. Press, Ames, Iowa, USA, $629 \mathrm{p}$.

SPSS Statistics 17.0. (2008) SPSS for Windows. SPSS Inc. 2008. Steel, R.G.D., J.H.

Steel, R.G.D., Torri, J.H. and Dickey, D.A. (1997) "Principles and Procedures of Statistics: A Biometrical Approach", $3^{\text {rd }}$ ed., Mc Graw-Hill, New York. .
Tan, S.L. and Morrison, W.R. (1979) Lipids in the germ, endosperm and pericarp of the developing maize kernel. J. Am. Oil Chem. Soc. 56, 759-764.

Uribelarrea, M., Below, F.E. and Moose, S.P. (2004) Grain composition and productivity of maize hybrids derived from the Illinois Protein strains in response to variable nitrogen supply, Crop Sci. 44, 1593-1600.

Wang, X.L. and Larkins, B.A. (2001) Genetic analysis of amino acid accumulation in opaque-2 maize endosperm. Plant Physiol. 125, 1766-1777.

Weber, E.J. (1970) Lipids of maturing grain of corn (Zea mays L) II: Changes in polar lipid. J. Amer. Oil Chem. 46(9), 485-488.

Zai, S.W. and Gao, J. (2001) Nutritional value and developing prospect of high-oil corn. Cereal Feed Ind. 6, 41-42.

Zhang, Y.H., Kato, M. and Isobe, K. (1995) Dissociated control by glycyrrhizin of proliferation and IL-2 production of murine thymocytes. Cell Immunol. 162(1), 97-104.

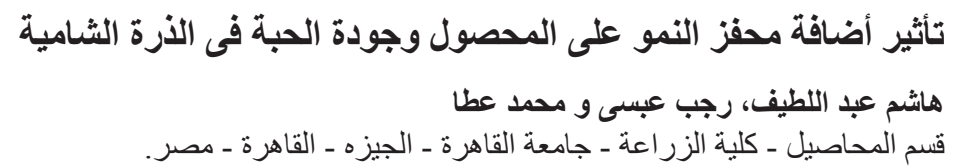

يطلق أسم محفز ات النمو أو المحفز ات الحيوية على المكملات الغذائية التى تحتوى على المو اد الغذائية، الأحماض فئل التهاض

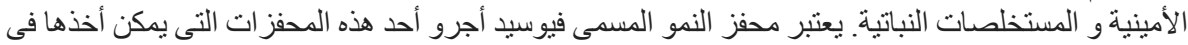

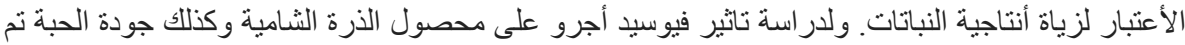

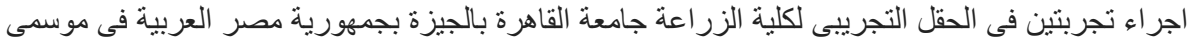

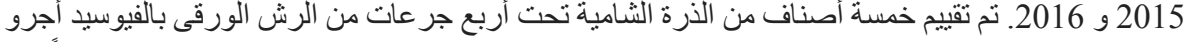

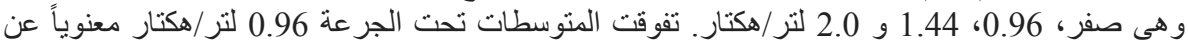

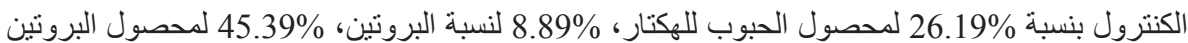

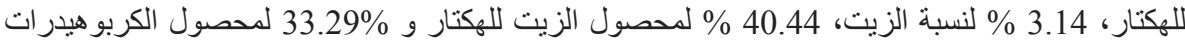

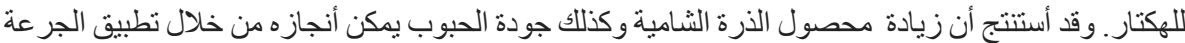
المنخفضة من الفيوسيد أجرو (0.96 لتر /هكتار ). 